\title{
The effect of social media marketing on purchase intention in fashion industry
}

\author{
Dewi $^{a}$, Maria Grace Herlina ${ }^{b^{*}}$ and Adine Esther Mutiha Boetar Boetar ${ }^{a}$
} \author{
Indonesia \\ C H R O N I C L E \\ Article history: \\ Received: October 25, 2021 \\ Received in revised format: No- \\ vember 20, 2021 \\ Accepted: January 5, 2022 \\ Available online: January 52022 \\ Keywords: \\ Brand Awareness \\ Fashion Industry \\ Purchase Intention \\ Social Media \\ Social Media Marketing
}

${ }^{a}$ Business Creation Program, Management Department, BINUS Business School Undergraduate Program, Bina Nusantara University, Jakarta, 11480,

${ }^{b}$ Management Department, BINUS Business School Undergraduate Program, Bina Nusantara University, Jakarta, 11480, Indonesia

\section{A B S T R A C T}

The research is aimed to understand the influence of social media in marketing on brand awareness, which in the end influences purchase intention in the fashion industry. It uses a qualitative approach to study the three variables, namely social media marketing, purchase intention, and brand awareness. In this research, the needed number of samples are 270 respondents and data are processed using SPSS to conduct validity, reliability, normality, classic assumption, single, and multiple linear regression. Results from SPSS are also used in the Sobel Test. Complemented with secondary data from literature studies, the hypothesis is tested. From the test, every hypothesis has significant positive influences. In conclusion, a brand can influence purchase intention significantly by utilizing social media marketing. This works by stimulating brand awareness to consumers to influence purchase intention.

\section{Introduction}

In this era, many aspects have been affected by technological development, enabling everything to be done online. This includes marketing especially in the fashion industry. All this time, the way marketers advertise their product is through conventional ways, such as advertisement slots in magazines, television, billboards, and radio (Tudor, 2016). But now development has innovated the way of marketing to digital marketing. Among many, social media, deemed to be one of the most used platforms according to The Indonesian Agency for Creative Economy (Bekraf, 2017). The reason behind it is because most of the society in Indonesia nowadays spent much of their time on social media. This can be viewed from the $10 \%$ increase of internet users in Indonesia in 2019 according to the Indonesian Internet Service Provider Association or APJII (The Jakarta Post, 2019). Around $64.8 \%$ or 171 million of the Indonesian population are active internet users and most have social media. On average, Indonesian internet users spend around 3 hour and 26 minutes a day on the net, specifically social media (KOMINFO, 2017). This put the country on the fourth highest social media in the world. Furthermore, UNESCO research (KOMINFO, 2018) shows around 4 out of 10 of the average Indonesian are active on Facebook (3.3. million users) and WhatsApp (2.9 million users). Moreover, Indonesia ranked fourth (56 million accounts) on most Instagram users, behind the United States, Brazil, and India (Wardani et al., 2019).

Fashion's brand presence on social media aims to effectively communicate to the masses, sharing the most up-to-date information of products. This information is displayed on the social media page of the said marketer. Paid features such as paid adverts enable marketers to further their reach by utilizing the concept of eWOM or electronic word-of-mouth. Here, the marketer invites users and public figures alike to share their experience with the product, thus cooperating in the promotion of the product (Nash, 2018).

* Corresponding author.

E-mail address: herlina01@binus.edu (M. G. Herlina)

(C) 2022 by the authors; licensee Growing Science, Canada. doi: $10.5267 /$ j.ijdns.2022.1.002 
Social media marketing is utilized to increase consumer purchase intention towards a product. It is deemed more honest because of its ability to create space for open discussions and sharing of the brand rather than controlling the perceived image. Therefore, it increases positivity towards the brand, influences stronger commitment, and influences the purchase intention process because consumers felt a good relationship with the said brand (Laksamana, 2018).

The presence of social media also influences brand awareness. This is because the media serves as an effective two-way communication platform, ideal for increasing customers' value, achieved by sharing information on relevant events or activity (Laksamana, 2018). Product exposure enables consumers to remember or recall the said brand memory wise, because of its descriptive and evaluative nature (Foroudi, 2018).

\section{Related works}

In this research, three variables will be discussed, which are social media marketing, purchase intention, and brand awareness. Social media marketing is the usage of online platforms, specifically social media to increase consumer's brand recognition using eWOM (Farook et al., 2016). Purchase intention is the consumer's behavior of purchasing that tends to emerge after gathering information and evaluating a product (Tariq et al., 2017). Brand awareness is the consumer's ability to recognize and identify a brand in any circumstances, based on the level of familiarity through continuous exposure (Foroudi, 2018).

Social media marketing is more honest towards consumers because of how it works; conveys what the brand has to offer rather than controlling the image perceived by the consumer. Thus, it increases positive attitude towards brand, influences stronger commitment as well as purchase intention (Laksamana, 2018). EWOM ability as informant and giver of recommendation also influences purchase intention (Kudeshia et al., 2016).

Hypothesis 1 (H1): There is an influence between social media marketing and purchase intention.

Prior research states that social media marketing has an effective influence towards brand awareness. Social media is considered an ideal two-way interaction platform to increase customers' value through information sharing and interaction with consumers (Laksamana, 2018). Product exposure of a brand helps increase the consumer's recall and recognition of a brand because of its descriptive and evaluative nature (Foroudi, 2018).

Hypothesis 2 (H2): There is an influence between social media marketing and brand awareness.

Brand awareness helps consumers identify a brand in certain product categories, able to influence consumers to prompt a decision in purchasing, therefore influencing purchase intention (Tariq et al., 2017). A high-level brand awareness is a condition where it positively motivates consumer's purchase intention. However, the level of brand awareness is also influenced by product reviews by other consumers with prior experience. Higher reviewer's credibility leads to consumer trust, which eventually influences purchase intention (Chakraborty, 2019).

Hypothesis 3 (H3): There is an influence between brand awareness and purchase intention.

Social media is a platform to present a brand's proposition and its offering to attract consumers. According to Dehghani and Tumer, social media is effective for increasing consumer's brand identification. Purchase intention is also affected by recent technological development. As stated by Daeun Kim, consumers very often gather information through social media before concluding to a decision to purchase a product, either by reading or watching reviews by influencer, public figure, or an expert (Ansari et al., 2019).

The use of social media is one of the alternatives for branding. Muntinga, Moorman, and Smith argue that social media has become a platform for a brand to share product offering, including new product entry and developing a brand awareness that will influence response towards it. But not all consumers give a positive response. According to Hutter, Hautz, and Fuller after consumer's brand awareness developed, there will be a positive or negative response towards a product that will eventually lead to the decision to purchase and use or not to purchase and use a brand's product (Pütter, 2017).

Based on research stated in the previous hypothesis, it can be assumed that there are certain factors, including brand awareness, that can strengthen the influence between social media marketing and purchase intention.

Hypothesis 4 (H4): There is an influence between social media marketing and purchase intention mediated by brand awareness.

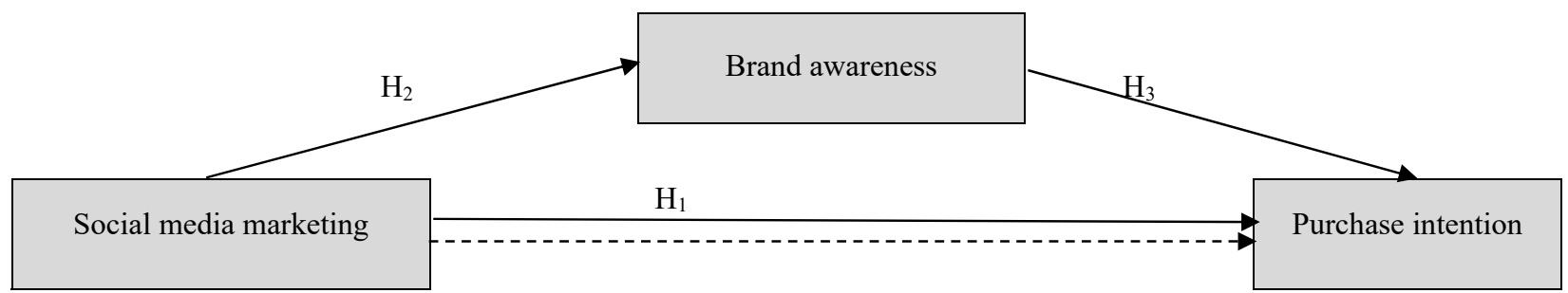

Fig. 1. The proposed study 


\section{Method}

As quantitative research, all necessary data are gathered from two sources. Data that is collected right from the original resource called primary data and data that collected by other researchers before current study that will be used as a source or guideline for this current study called secondary data (Sekaran et al., 2016). Primary data is gathered by utilizing digital questionnaire tools from Google Form, in which a questionnaire link is spread to respondents that have social media, tend to do online shopping, and live in Jakarta and Tangerang, Indonesia. Questions listed in the questionnaire will be answered by using the Likert scale. Of the five-scale listed, one indicates strongly disagree and five strongly agree. According to Sugiyono (2017), data gathering will be effective if a certain number of samples is satisfied or achieved and spread over a large area. In this research the needed number of samples is 270 respondents. The number is derived from the number of indicators with a five to ten times the minimum assumption. Because this research has 27 indicators to measure the three variables, the minimum sample needed is 270 respondents or ten times the number of indicators (Hair et al., 2014). Meanwhile, to satisfy the need for theories, secondary data collected from books, scientific journals, and relevant articles to the research topic.

This research utilizes IBM SPSS STATISTICS 2.0. SPSS (Statistical product and Service Solution), well-suited for data processing and analysis and its flexibility for research on a variety of topics, such as social sciences, natural sciences, as well as business research (George et al., 2019). Gathered data is then processed by utilizing several testing methodologies: validity testing, reliability testing, normality testing, classic assumption testing (linearity, multicollinearity, heteroskedasticity), also simple and multiple linear regression testing. To test the significance of the mediator variable, a Sobel Test conducted, of which the calculation process uses Calculation for The Sobel Test made by Preacher and Leonardelli, in which it only needs to input the $a$ and $b$ coefficient and both coefficient's standard error ( $S a$ and $S b)$.

\section{Results}

\subsection{Descriptive analytics}

Fig. 1 is the profile of the respondents based on gender, age, level of education, occupation, domicile, and average monthly income. Out of the 287 samples gathered, 270 samples were used to take as per prior calculation.

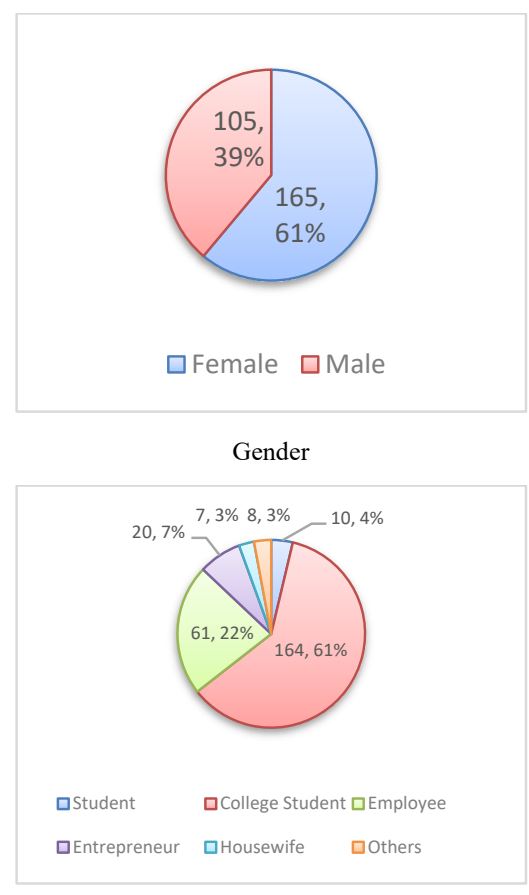

Occupation

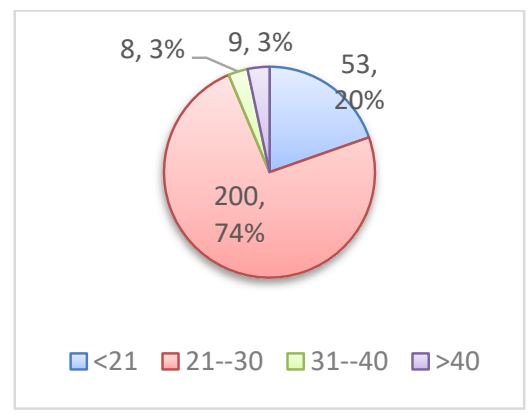

Age

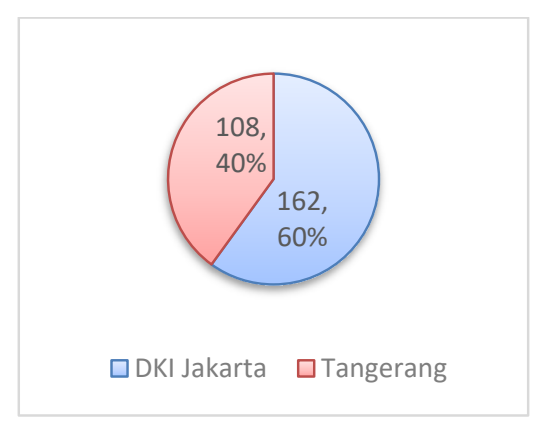

Domicil

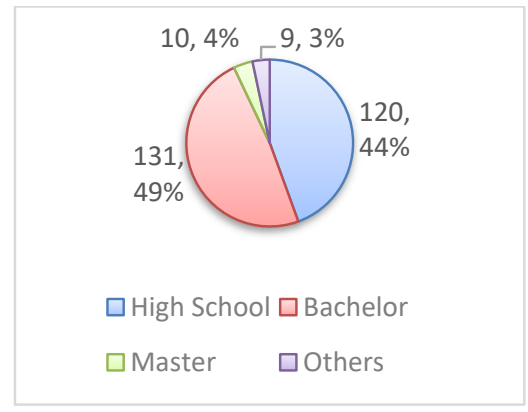

Education

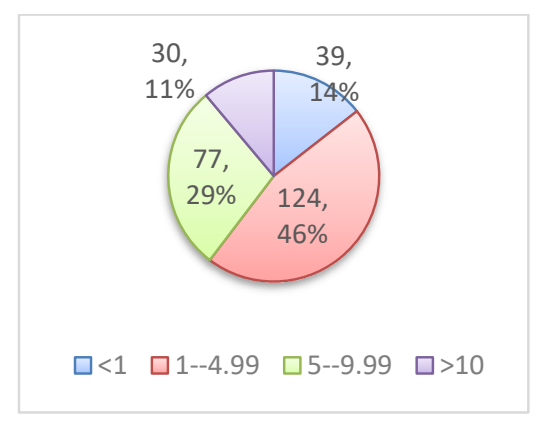

Monthly Income $\left(\times 10^{6}\right)$

Fig. 2. Personal characteristics of the participants

Fig. 2 presents the summary of the personal characteristics of the participants in this survey. As we can observe from the results of the figure, most participants were female in this survey. In addition, about $74 \%$ of them aged 21 to $30,20 \%$ of the participants aged less than 21 years. Nearly half of the participants had only high school education and the rest of them mostly had some bachelor science degree. Moreover, more than $60 \%$ of the participants in our survey were college students. Finally, in terms of income, two third of the participants has average monthly income.

Table 1 also presents the summary of the validity test. Indicators are reliable if the $\alpha$ is 0.7 or greater (George et al., 2019). Same as the result of the validity test, all 27 indicators are reliable after testing. 
Table 1

Result of Validity Test

\begin{tabular}{|c|c|c|c|c|}
\hline Variable & Indicator & Corrected Item-Total Correlation & R Table & Decision \\
\hline \multirow{10}{*}{ Social Media Marketing } & SMM1 & .576 & .1194 & Valid \\
\hline & SMM2 & .630 & .1194 & Valid \\
\hline & SMM3 & .439 & .1194 & Valid \\
\hline & SMM4 & .401 & .1194 & Valid \\
\hline & SMM5 & .467 & .1194 & Valid \\
\hline & SMM6 & .521 & .1194 & Valid \\
\hline & SMM7 & .465 & .1194 & Valid \\
\hline & SMM8 & .520 & .1194 & Valid \\
\hline & SMM9 & .575 & .1194 & Valid \\
\hline & SMM10 & .546 & .1194 & Valid \\
\hline \multirow{6}{*}{ Brand Awareness } & BA1 & .528 & .1194 & Valid \\
\hline & BA2 & .545 & .1194 & Valid \\
\hline & BA3 & .473 & .1194 & Valid \\
\hline & BA4 & .426 & .1194 & Valid \\
\hline & BA5 & .343 & .1194 & Valid \\
\hline & BA6 & .368 & .1194 & Valid \\
\hline \multirow{11}{*}{ Purchase Intention } & PI1 & .574 & .1194 & Valid \\
\hline & PI2 & .634 & .1194 & Valid \\
\hline & PI3 & .604 & .1194 & Valid \\
\hline & PI4 & .495 & .1194 & Valid \\
\hline & PI5 & .547 & .1194 & Valid \\
\hline & PI6 & .477 & .1194 & Valid \\
\hline & PI7 & .549 & .1194 & Valid \\
\hline & PI8 & .463 & .1194 & Valid \\
\hline & PI9 & .483 & .1194 & Valid \\
\hline & PI10 & .485 & .1194 & Valid \\
\hline & PI11 & .469 & .1194 & Valid \\
\hline
\end{tabular}

Table 2 also shows the results of the Cronbach alpha for three variables of the survey. As we can observe from the results, all variables maintain reliable values.

Table 2

Result of Reliability Test

\begin{tabular}{lccc}
\hline \multicolumn{1}{c}{ Variable } & Cronbach's Alpha & N of Items & Decision \\
\hline Social Media Marketing & .826 & 10 & 6 \\
Brand Awareness & .713 & Valid & Valid \\
Purchase Intention & .843 & 11 & Valid \\
\hline
\end{tabular}

\subsection{Normality test}

In this research, normality testing is conducted by using the Kolmogorov-Smirnov methodology, aimed for research with a large sample number or more than fifty respondents. Data is normally distributed if Sig. in the SPSS table is not significant or more than 0.05 (Field, 2013). After testing, the Sig. is 0.391 , bigger than 0.05, therefore it can be determined that the data are normally distributed.

Table 3

The results of Kolmogorov-Smirnov

\begin{tabular}{|c|c|c|}
\hline & & dardized Residual \\
\hline \multicolumn{2}{|c|}{$\mathrm{N}$} & 270 \\
\hline \multirow{2}{*}{ Normal Parameters ${ }^{\mathrm{a}, \mathrm{b}}$} & Mean & $0 \mathrm{E}-7$ \\
\hline & Std. Deviation & .33110573 \\
\hline \multirow{3}{*}{ Most Extreme Differences } & Absolute & .055 \\
\hline & Positive & .044 \\
\hline & Negative & -.055 \\
\hline \multicolumn{2}{|c|}{ Kolmogorov-Smirnov Z } & .901 \\
\hline \multicolumn{2}{|c|}{ Asymp. Sig. (2-tailed) } & .391 \\
\hline
\end{tabular}

a. Test distribution is Normal.

b. Calculated from data.

\subsection{Classic assumption test}

A classic assumption testing is a statistical requirement in regression analysis. In this research, the testing utilizes simple regression and multiple regression testing, therefore it is necessary to conduct linearity, multicollinearity, and 
heteroskedasticity testing. All three classic assumption testing has been conducted and the result is fulfilled, therefore the research can move on to regression.

\subsection{Linear regression test}

In simple linear regression and multiple regression tests, if the Sig. the value in the ANOVA table is lower than 0.05, it means that there is a cause-and-effect relationship. Subsequently, in the unstandardized coefficients table, positive B value indicates positive relationship between two variables or between independent and dependent variables. The B value and Std. Error is used as a coefficient to conduct path analysis and Sobel Test.

The simple linear regression testing is conducted twice, substructure 1 for testing path $c$ (total effect) and substructure 2 for testing path $a$, needed for finding the indirect effect coefficient. From the simple linear regression test result, it indicates that there is a positive cause and effect relationship between social media marketing and purchase intention $(c)$ and between social media marketing and brand awareness $(a)$. After conducting the simple linear regression test, the multiple regression testing is conducted to find the cause-and-effect relationship between social media marketing and purchase intention ( $\left(c^{\prime}\right)$, identified as direct effect. A test is also conducted to identify the cause-and-effect relationship between brand awareness and purchase intention $(b)$, needed for completing the indirect effect coefficient. From the multiple linear regression test result, it indicates that there is a positive cause and effect relationship on path $c^{\prime}$ and path $b$.

Table 4

Result of Simple and Multiple Linear Regression Test

\begin{tabular}{|c|c|c|c|c|c|c|}
\hline & Model & & Coefficients & Standardized Coefficients & $\mathrm{t}$ & Sig. \\
\hline & & B & Std. Error & Beta & & \\
\hline 1 & (Constant) & 1.264 & .180 & & 7.011 & .000 \\
\hline 1 & meanSMM & .693 & .044 & .692 & 15.676 & .000 \\
\hline
\end{tabular}

a. Dependent Variable: meanPI

\begin{tabular}{|c|c|c|c|c|c|c|}
\hline & \multirow[t]{2}{*}{ Model } & \multicolumn{2}{|c|}{ Unstandardized Coefficients } & \multirow{2}{*}{$\begin{array}{c}\text { Standardized Coefficients } \\
\text { Beta }\end{array}$} & \multirow[t]{2}{*}{$\mathbf{t}$} & \multirow[t]{2}{*}{ Sig. } \\
\hline & & B & Std. Error & & & \\
\hline \multirow{2}{*}{1} & (Constant) & 1.641 & .219 & & 7.476 & .000 \\
\hline & meanSMM & .596 & .054 & .560 & 11.077 & .000 \\
\hline
\end{tabular}

a. Dependent Variable: meanBA

\begin{tabular}{|c|c|c|c|c|c|c|}
\hline & \multirow[t]{2}{*}{ Model } & \multicolumn{2}{|c|}{ Unstandardized Coefficients } & \multirow{2}{*}{$\begin{array}{c}\text { Standardized Coefficients } \\
\text { Beta }\end{array}$} & \multirow[t]{2}{*}{$\mathbf{t}$} & \multirow[t]{2}{*}{ Sig. } \\
\hline & & B & Std. Error & & & \\
\hline \multirow{3}{*}{1} & (Constant) & .766 & .185 & & 4.152 & .000 \\
\hline & meanSMM & .512 & .050 & .511 & 10.306 & .000 \\
\hline & meanBA & .303 & .047 & .322 & 6.493 & .000 \\
\hline
\end{tabular}

a. Dependent Variable: meanPI

According to Barron and Kenny (1986) a variable succeeds as a mediator between two variables if the basic relationship values decrease where a mediator is included in the relationship (Jose, 2013). Based on the below figure, it can be inferred that the coefficient value changes. Its basic relationship coefficient is reduced from $c=0.693$ (total effect) to $c^{\prime}=0.512$ (direct effect) when brand awareness mediates the relationship between social media marketing and purchase intention. This change indicates that brand awareness is an able mediator variable for the independent and dependent variable relationship.

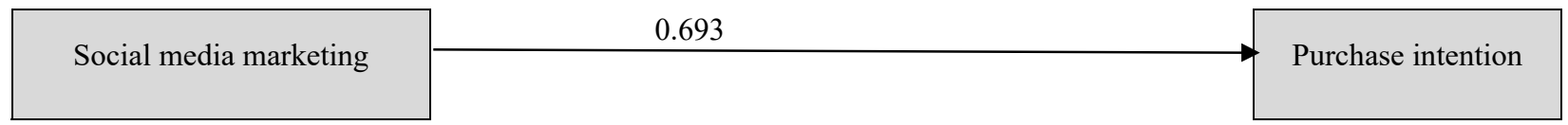

Fig. 3. The Model and Result of Total Effect

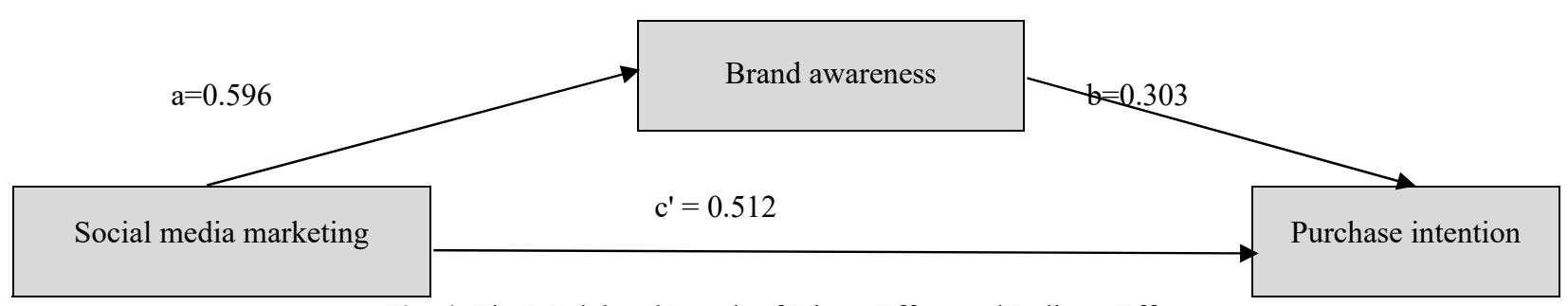

Fig. 4. The Model and Result of Direct Effect and Indirect Effect 
However, the reduction of coefficient does not indicate whether the mediator variable has a significant effect. Therefore, the Sobel Test is conducted. By using the Website Calculation for The Sobel Test, it is discovered that the p-value is lower than the probability $(0.05)$, which is 0.00000003 . This means that the mediator variable is significant, therefore effective.

\begin{tabular}{|c|c|c|c|c|}
\hline Input: & & Test statistic: & Std. Error: & $p$-value: \\
\hline a 0.596 & Sobel test: & 5.56674224 & 0.03244052 & $3 e-8$ \\
\hline b 0.303 & Aroian test: & 5.54978361 & 0.03253965 & $3 e-8$ \\
\hline$s_{a} 0.054$ & Goodman test: & 5.58385728 & 0.03234108 & $2 e-8$ \\
\hline$s_{b} 0.047$ & Reset all & & Calculate & \\
\hline
\end{tabular}

Fig. 5. The Result of Sobel Test

\section{Discussion}

The Sig. value of H1 is $0.000<0.05$, means that the influence of social media marketing to purchase intention is significant, therefore in line with research results conducted by Laksamana, in which states that social media marketing in fashion industry affects the purchase intention (Laksamana, 2018). Furthermore, Kudeshia and Kumar also state that social media marketing's eWOM in a form of online reviews can significantly affect the purchase intention (Kudeshia et al., 2016). Therefore, $\mathrm{H} 1$ is acceptable.

The Sig. the value of $\mathrm{H} 2$ is $0.000<0.05$ signifies that social media marketing significantly affects brand awareness. It is consistent with the research result from Alnsour and Tayeh, which states that social media marketing has a positive impact on brand awareness. Foroudi also states that a brand's product exposure enables consumers to identify and recognize the brand because of its descriptive and evaluative information nature (Foroudi, 2018). Therefore, H2 is acceptable.

The H3 Sig. value is $0.000<0.05$. This means that brand awareness has a significant positive influence on purchase intention, in line with the research conducted by Tariq, Abbas, and Abrar, where brand awareness helps consumers recognize and understand the brand's product, eventually influencing the decision to purchase (Tariq et al., 2017). Therefore, H3 is acceptable.

Table 5

Conclusion of Hypotheses Test

\begin{tabular}{cccccc}
\hline Hypotheses & Sig. & B & p-value & Prob. & Description \\
\hline SMM $\rightarrow$ PI & 0.000 & 0.693 & - & 0.05 & Positive, Significant \\
SMM $\rightarrow$ BA & 0.000 & 0.596 & - & 0.05 & Positive, Significant \\
BA $\rightarrow$ PI & 0.000 & 0.303 & - & 0.05 & Positive, Significant \\
SMM $\rightarrow$ BA $\rightarrow$ PI & 0.000 & - & 3e-8 & 0.05 & Positive, Significant \\
\hline
\end{tabular}

The path analysis result from regression indicates that the mediator variable (brand awareness) has mediated the relationship between social media marketing and purchase intention. Its significance in the relationship is shown from Sobel's Test pvalue of $0.00000003<0.05$, which indicates the presence of a mediator variable is significant. This result is in line with the literature review from Kim, in which a consumer will decide his or her purchase intention after finding a significant amount of knowledge regarding the said brand's product. One of it is from reviews on social media (Ansari et al., 2019) or other available sources. Another study confirms that social media marketing is the right tool to conduct branding, in order to develop brand awareness that will, in the end, influence consumer's response to the brand (Pütter, 2017). Therefore, H4 is acceptable.

\section{Conclusion}

Based on the research that has been done, a consumer's purchase intention in Jakarta and Tangerang is influenced by social media marketing. Social media has become a favorite for fellow marketers in the fashion industry to market their products. And many, nowadays spend time on social media. With the high usage of social media, reaching consumers from this platform became one the primary reasons for product marketing. Social media marketing, including the utilization of social media's built-in ads management and endorsement system that is interactive and attractive to gather more audience and encourage the consumers to purchase. Furthermore, using the right combination of photo, caption, model, and or endorser will encourage prospective consumers to purchase, even though the brand is new in the market.

After thorough research, we have found that a mediator variable is imperative in the increase of relationship quality between social media marketing and purchase intention, in which is brand awareness. The right utilization of social media as a marketing tool will foster an awareness to a brand-also known as brand awareness. The presence of brand awareness will familiarize the consumers in Jakarta and Tangerang towards a brand, where the higher the awareness level means higher possibility for consumers to quickly remember and recognize a certain brand. Fostering or developing a brand awareness in a consumer takes time. But if done correctly and hits embedded in the consumer's mind, the probability for loyalty to be formed is high, leading to a repeat order in the future. 


\section{References}

Ansari, S., Ansari, G., Ghori, M. U., \& Kazi, A. G. (2019). Impact of Brand Awareness and Social Media Content Marketing on Consumer Purchase Decision. Journal of Public Value and Administration Insights, 2(2), 5-10. https://doi.org/10.31580/jpvai.v2i2.896

BEKRAF. (2017, April 10). Data Statistik dan Hasil Survei Ekonomi Kreatif. April 1, 2020. http://staging.bekraf.go.id/berita/page/17/infografis-data-statistik-dan-hasil-survei-khusus-ekonomi-kreatif

Chakraborty, U. (2019). The impact of source credible online reviews on purchase intention: The mediating roles of brand equity dimensions. Journal of Research in Interactive Marketing, 13(2), 142-161. https://doi.org/10.1108/JRIM-06-20180080

Farook, F. S., \& Abeysekara, N. (2016). Influence of Social Media Marketing On Customer Engagement. International Journal of Innovative Research \& Development, 5(12), 115-125

Field, A. (2013). Discovering Statistics Using IBM SPSS Statistics. $4^{\text {th }}$ ed., SAGE Publications

Foroudi, P. (2018). Influence of brand signature, brand awareness, brand attitude, brand reputation on hotel industry's brand performance. International Journal of Hospitality Management, 76, 271-285. https://doi.org/10.1016/j.ijhm.2018.05.016

George, D., \& Mallery, P. (2019). IBM SPSS Statistics 25 Step by Step: A Simple Guide and Reference (Fifteenth). Routledge

Hair, J. F., Black, W. C., Babin, B. J., \& Anderson, R. E. (2014). Multivariate Data Analysis. $7^{\text {th }}$ ed., Pearson Education LImited

Jose, P. E. (2013). Doing Statistical Mediation \& Moderation. The Guildford Press

KOMINFO. (2017, January 3). Pemerintah ingin media sosial dimanfaatkan untuk hal produktif. March $20,2020$. https:/www.kominfo.go.id/content/detail/8637/pemerintah-ingin-media-sosial-dimanfaatkan-untuk-hal-produktif/0/sorotan media

KOMINFO. (2018, August 30). Angka Penggunaan Media Sosial Orang Indonesia Tinggi, Potensi Konflik juga Amat Besar. March 20, 2020. https://kominfo.go.id/content/detail/14136/angka-penggunaan-media-sosial-orang-indonesia-tinggi-potensi-konflik-juga-amat-besar/0/sorotan_media

Kudeshia, C., \& Kumar, A. (2016). Social eWOM: does it affect the brand attitude and purchase intention of brands? Management Research Review, 40(3), 310-330. https://doi.org/10.1108/MRR-07-2015-0161

Laksamana, P. (2018). Impact of Social Media Marketing on Purchase Intention and Brand Loyalty: Evidence from Indonesia's Banking Industry. International Review of Management and Marketing, 8(1), 13-18

Nash, J. (2018). Exploring how social media platforms influence fashion consumer decisions in the UK retail sector. Journal of Fashion Marketing and Management, 23(1), 82-103. https://doi.org/10.1108/JFMM-01-2018-0012

Pütter, M. (2017). The Impact of Social Media on Consumer Buying Intention. Journal of International Business Research and Marketing, 3(1), 7-13. https://doi.org/10.18775/jibrm.1849-8558.2015.31.3001

Sekaran, U., \& Bougie, R. (2016). Research Methods for Business: a skill-building approach. $7^{\text {th }}$ ed. Wiley. https://doi.org/10.1017/CBO9781107415324.004

Sugiyono. (2017). Metode Penelitian Kuantitatif, Kualitatif, dan R\&D. Bandung: Alfabeta

Tariq, M., Abbas, T., Abrar, M., \& Iqbal, A. (2017). EWOM and brand awareness impact on consumer purchase intention: mediating role of brand image. Pakistan Administrative Review, 1(1), 84-102

The Jakarta Post. (2019, May 19). Indonesia has 171 million internet users: Study. April 1, 2020. https://www.thejakartapost.com/life/2019/05/18/indonesia-has-171-million-internet-users-study.html

Wardani, Agustin Setyo. (2019, June 26). Jumlah Pengguna Instagram dan Facebook Indonesia Terbesar ke-4 di Dunia. March 20, 2020. https://www.liputan6.com/tekno/read/3998624/jumlah-pengguna-instagram-dan-facebook-indonesia-terbesarke-4-di-dunia 
(C) 2022 by the authors; licensee Growing Science, Canada. This is an open access article distributed under the terms and conditions of the Creative Commons Attribution (CC-BY). license (http://creativecommons.org/licenses/by/4.0/). 